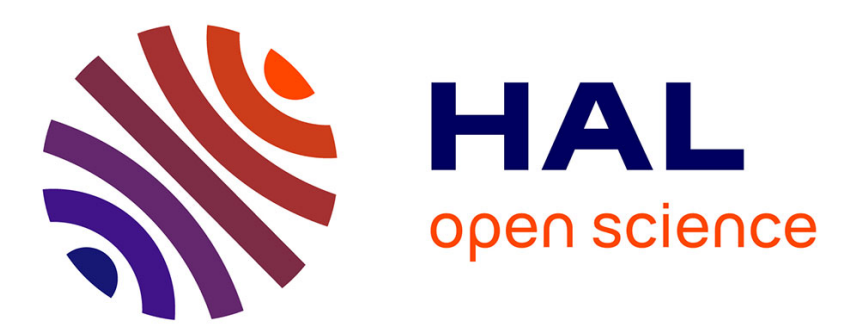

\title{
Inside the credit boom: Competition, Segmentation and Information - evidence from Serbian credit market
} Jasna Dimitrijevic, Boris Najman

\section{To cite this version:}

Jasna Dimitrijevic, Boris Najman. Inside the credit boom: Competition, Segmentation and Information - evidence from Serbian credit market. Comparative Economic Studies, 2008, 50, pp.217-252. $10.1057 /$ ces.2008.1. hal-00266715

\section{HAL Id: hal-00266715 https://hal.science/hal-00266715}

Submitted on 30 Mar 2008

HAL is a multi-disciplinary open access archive for the deposit and dissemination of scientific research documents, whether they are published or not. The documents may come from teaching and research institutions in France or abroad, or from public or private research centers.
L'archive ouverte pluridisciplinaire HAL, est destinée au dépôt et à la diffusion de documents scientifiques de niveau recherche, publiés ou non, émanant des établissements d'enseignement et de recherche français ou étrangers, des laboratoires publics ou privés. 


\title{
INSIDE THE CREDIT BOOM: COMPETITION, SEGMENTATION AND INFORMATION EVIDENCE FROM THE SERBIAN CREDIT MARKET
}

\author{
---Forthcoming in Comparative Economic Studies---
}

\author{
Jasna Dimitrijevic* \\ Centre d'Economie de la Sorbonne \\ (University Paris I and CNRS) \\ 106/112 Boulevard de l'Hôpital \\ 75647 Paris Cedex 13, France \\ Center for Advanced Economic Studies (CEVES) \\ Lazarevačka 1, \\ 11000 Belgrade, Serbia \\ e-mail: jasna@,ceves.org.yu \\ Boris Najman* \\ Centre d'Economie de la Sorbonne \\ (University Paris I and CNRS) \\ 106/112 Boulevard de l'Hôpital \\ 75647 Paris Cedex 13, France \\ e-mail: bnajman@univ-paris1.fr
}

December 2007

\footnotetext{
* We are very grateful to Kori Udovicki for her precious comments and suggestions in performing the banking survey and analysis of collected data. We want to thank the organizers of the Conference on Risk, Regulation and Competition: Banking in Transition Economies in Ghent University, 1-2 September 2006.

We want especially to thank Vesna Dimitrijevic for her help in database construction. We would also like to thank Olivier Lamotte, Ramona Jimborean, Milica Uvalic, Richard Pomfret, Jules-Armand Tapsoba and an anonymous referee for very helpful comments on an earlier draft and Irena Cerovic and Branka Maricic for their assistance on language editing. All remaining errors are our own.
} 


\section{Abstract}

In the context of rapid credit growth, the present paper investigates the supply side of the Serbian credit market. We use an on-site survey of banks aiming to describe financial intermediation by scanning the interest rates and other lending terms in Serbia. Findings from the survey suggest that the credit market is largely non-homogeneous and segmented, but with an increasing presence of competition. Motivated by these findings, we further use an original data set from the financial statements of Serbian banks for a time span of 2001 to 2005. Using both qualitative and quantitative approaches, we observe the existence of segments in the banking sector. One segment is characterized by a stronger presence of foreign banks, higher transparency of clients and stronger effects of competition on lending interest rates (lower spreads). Another segment is one with more domestic banks, less transparent borrowers and relatively higher banks' market power (higher intermediation spreads). The sources of segmentation are in our case represented by funding costs and ultimately by bank ownership. Using the GLS estimator on our panel dataset, we estimate the main determinants of bank interest margins as indicators of market power on the individual bank level. Then we test the effect of foreign bank presence on overall asset quality. We use the model developed by Dell'Ariccia and Marquez (2004) in order to explain the results of our regressions and to describe the segmentation. Their model stresses the role of information in shaping bank competition, where a lender with an information advantage (in case of Serbia, local banks) competes with an outside lender (foreign-owned banks) with less information, but potentially having a cost advantage in extending a loan. We believe that the proposed pattern of segmentation is in place in the Serbian lending market. The findings from the qualitative survey support this argument as well.

Key words: credit growth, banking competition, bank spreads, credit risk, foreign banks JEL classification: G21, P34, E43 


\section{INTRODUCTION}

Banking systems in transition economies have some specific features and have been the subject of an extensive list of studies during the last two decades. These markets have experienced a rapid credit growth driven by integration into international capital markets trough foreign banks which entered their banking markets. The resulting credit boom represents a concern to these countries' monetary authorities in their aim to maintain financial stability, trade balance, and control inflation ${ }^{1}$. Second, banks in these systems were originally entirely or at least significantly owned by state and, in the eve of the transition era, their assets were burdened by bad loans. Thus, the incoming transition governments faced the challenge of applying an adequate reform path in a way of attaining an efficient banking system. In practice, as in the wide literature treating the issue, the winning solution was to allow the privatization of state-owned banks by foreign banks (EBRD, 2006). This solution was supposed to restore confidence in the banking sector, to improve risk management practices, and thus reach an efficient level of financial intermediation (all financial systems of Central and Eastern European transition economies were dominated by banks, while financial markets were largely underdeveloped).

A credit boom was an underlying issue of banking sectors in all transition countries, partly boosted by the re-entry of cash into the banking system and the revival of deposits. On the other hand, liberalization of the banking market led to increased foreign bank presence in these countries and became the main driving force of credit growth. In addition to bringing the domestically lacking fresh capital, foreign banks were expected to import better management practices and know-how. Foreign banks established themselves in Serbia as de novo entrants, through privatization of state-owned banks (after prior cleaning of their balance sheets from bad loans, which were taken over by the government, e.g. in the case of Alfa Bank - former Jubanka), or by acquisition of small local private banks (for example, HypoAlpe-Adria Bank bought Depozitno Kreditna banka) ${ }^{2}$. The newly established foreign banks financed a large part their operations through credit lines from their West-European mother banks (unlike local banks, which mostly collected their funding locally - domestic deposits and in some cases even loans from the foreign-owned banks). This bountiful source combined with a largely underdeveloped and shallow lending market provides a field for increasing competition between new arriving banks and existing domestic banks for their market shares.

In the present paper, we analyze the case of the Serbian banking system as representative of any liberalized banking market that experienced a rapid credit growth following the liberalization of capital flows. The share of total banking assets in possession of foreign banks increased from $0 \%$ in 2000 - the starting year of reforms and transition - to $67 \%$ at the end of 2005 (Table 2), while the average annual credit growth in the same period reached around $50 \%$ in nominal terms.

We are particularly interested in explaining the consequences of liberalization and the resulting banking competition on the structure of the credit market. In our analysis, we pay attention to the information aspect of the competition. Our conclusions are based on two types of data: one from the field survey of banks conducted in September 2005 and another from an original dataset with financial statements of the Serbian banking sector from 2000 to 2005 .

\footnotetext{
${ }^{1}$ See the conference on "Finance and consumption workshop" held in Florence on June 2006

${ }^{2}$ In all transition economies except Slovenia, after 10 years of transition foreign ownership became the dominant type of bank ownership.
} 
Our field survey ${ }^{3}$ resulted in some findings suggesting the existence of the segmentation of the credit market. Then, we explore the original dataset of Serbian banking sector in order to better understand the potential segmentation. We are inspired by the propositions of the model proposed by Dell'Ariccia and Marquez (2004) which explains market segmentation in the banking sectors of a liberalized market (like in transition and emerging countries) as a result of competition between an informed lender with a cost disadvantage (local bank) and an uninformed lender with a cost advantage (foreign bank). They qualified the resulting segmentation of the market as a "flight to captivity": the phenomenon where the less transparent - and thus more captive - borrowers concentrate with domestic banks while more transparent ones go to foreign banks attracted by lower interest rates. In other words, the quality of information held by domestic banks on the marginal and average borrower may decrease during the period of rapid credit growth. The empirical estimation, first of banking margin, then of asset quality, illustrated the plausible existence of the same phenomenon in the observed banking sector. Our main results show that foreign bank having significantly lower funding costs, are charging lower margins on their lending relative to margins of domestic banks.

In what follows, we first present a review of relevant literature (Section 2), followed by the background of the Serbian banking sector: the main characteristics of the banking and system together with a brief description of main macroeconomic features (Section 3). In section 4 , we proceed with the presentation of dataset, methodology of our empirical estimation and, present the variables. Section 5 contains our main estimation results and their implications supported by previous findings from the on-site banking survey. Section 6 concludes.

\section{REVIEW OF THE LITERATURE}

There are tree main strands of literature on banking in transition economies that closely relate to this study. The first treats issues of privatization, restructuring of the banking sector, and foreign bank entry. The second explores the credit boom and the underlying vulnerability of the banking sector. The last, which we refer to most, deals with competition among banks, the consequent segmentation, and risks on the market.

A wide range of the existing literature on banking in transition concerns privatization and foreign bank entry. It is evident that the traditional motivation for international bank expansion such as 'following the client' was not the main driver in the case of entering the banking sectors of transition countries. The existing literature widely explores the causes and effects of foreign bank entry in both developing and transition countries (for a comprehensive survey, see Clarke et al., 2001). However, these sources are ambiguous concerning empirically evidencing foreign versus domestic bank performance and the differences in the determinants of performance. Claessens, Demirguc-Kunt and Huizinga (2001) analyze the effects of foreign presence on domestic banking markets. Their empirical study is based on 7900 bank observations for 80 countries in the 1988-1995 period. Their main findings suggest that foreign banks have lower margins and profitability than domestic banks in developed countries, while the opposite holds in developing countries. Their empirical evidence also

\footnotetext{
${ }^{3}$ The banking survey was arranged in the period August-October 2005 with FREN (Foundation for the Advancement of Economics, founded by the Faculty of Economics of the University of Belgrade and the Center for Advanced Economic Studies - CEVES). The survey covered 19 out of 41 currently operating banks, representing $66 \%$ of total banking assets as of 30 September 2005 .
} 
suggests that an increased presence of foreign banks is associated with a reduction of profitability and margins for domestic banks. This study, however, does not include transition countries in its panel. In the same manner, there are a number of studies on transition countries treating the issue of performance differences (above all cost and profit efficiency) among different bank ownership categories. The empirical research of Bonin et al (2004), investigating the effect of bank privatization via foreign bank acquisition in the six transition countries from the CEE region, find that foreign-owned banks are the most efficient while government-owned banks are the least efficient. They do not explore the causes of such a gap, and the simple ownership effect could conceal many phenomena. The first intuitive answer that comes into mind for explaining the 'ownership' gap would be the quality of management. Rossi, Schwaiger, Winkler (2005) challenge this view testing the hypothesis of bad management (using methodology proposed by Berger and DeYoung, 1997) in banks in nine Central and Eastern European countries in the period 1995-2002. They analyze an inter-temporal relation across bank asset quality, capitalization and bank efficiency, and do not obtain any evidence of bad management in domestic banks, leaving the question of the causes of the performance gap opened. In our study, we aim primarily to explain the competition in the lending market by testing the determinants of bank margins and asset quality. In the framework of an imperfect market, we use market segmentation to explain the fact that there are significant differences in margins and asset quality across banks due to foreign bank presence.

More recent research explores the phenomenon of rapid private sector credit growth in transition countries. Rapid credit growth can trigger banking sector distress through two channels: macroeconomic imbalances and deterioration of loan quality, since risk assessment may suffer due to the vast amount of new loans extended (Duenwald et al. 2005). Kraft and Jankov (2005) analyzed the Croatian banking system, which has, similarly to the Serbian system, experienced phases of credit boom during the transition period. The early credit boom has led to a banking crisis while this was not the case with the later ones. They do not find a strong connection between rapid loan growth and credit quality. Their modeling results suggest that it is simplistic to point to rapid growth alone as the cause of banking problems. We believe that better understanding of lending terms and the effects of competition in the fast growing credit market that we study could be a key element for explaining the link between rapid credit growth and financial stability, as well as the efficacy of financial intermediation. Coricelli et al. (2006) show that there is no serious concern about the risk inherent to a credit boom in the household market. This is due to the relaxation of the liquidity constraint that existed in the pre-transition period. In order to answer the question about the impact of credit growth on banking sector stability, the role of information in shaping the structure of the lending market is introduced. Thus, indirectly, we arrive to the conclusion of a certain segmentation of the lending market induced by competition between banks with different levels of information about borrowers. We do not find evidence for a major concern at least not on the overall market. Certain segments could, however, attain an excessive credit risk level (at least measured by the official methodology). The latter is a result of competition leading to a shift of domestic banks to more captive but less transparent borrowers.

Competition among banks affects banks' net interest margins which, observed on the level of the banking sector, indicate the cost of financial intermediation and thus the efficiency of financial intermediation through the banking system. There is an extensive literature on competition in the banking industry ${ }^{4}$. It can be summarized as the following:

\footnotetext{
${ }^{4}$ See Vives (2001) 'Competition in the Changing World of Banking', for the overview of the literature
} 
competition enhances the efficiency of financial intermediation but can aggravate the risk of failure; the general trend in dealing with this issue is to introduce competition in banking, while checking the risks with capital requirements, appropriate supervision and reinforced market discipline with better information disclosure. Thus, the best regulatory response to the sharp competition in the banking sector possibly lies in an adequate institutional framework ${ }^{5}$.

The overall level of competition in a banking system is, however, difficult to measure. As some authors argue, it is driven by the contestability of a market and not by the number or the size of the banks (Claessens and Leaven, 2003). Systems with greater foreign bank entry and fewer entry and activity restrictions are found to be more competitive. Consistently with previous findings, Levine (2003) shows evidence in which impediments to foreign bank entry boost bank net interest margins. Mamatzakis et al. (2005) use Panzar Roze methodology to measure the level of competition in the banking sector in South Eastern European countries in the period 1998-2002. Their evidence shows that the dominant market form in these banking sectors is monopolistic competition, although competition intensifies over time. Aiming to explain the origin and consequences of intensifying competition in an emerging banking system open to foreign entrants, dell'Ariccia and Marquez (2003) propose a model based on asymmetric information and its role in shaping bank competition. The model explains the effects of financial liberalization on the creation of segments in the lending market with differences in bank spreads (market power) between different segments. In the present paper, we use the logic of this model to analyze the structure of the lending market in transition countries, on the example of Serbia.

\section{SERBIAN MONETARY TRENDS AND BANKING FRAMEWORK}

\subsection{Macro-economic and Monetary Framework (2000-2006)}

Serbian transitional reforms firmly started from the political shift to a democratic government in autumn 2000. In three years, inflation was reduced to a one-digit level, but then climbed to two digits again from 2004. The stabilizing mechanism for prices was based on the exchange rate peg. Since 2006, the central bank shifted to inflation targeting. The economy was achieving significant GDP growth, albeit starting from a low level base. Consistently high inflows of capital allowed the accumulation of foreign reserves. The increasing recapitalization of the banking system and high inflow of funds from abroad, combined with the revival of local deposits, led to above average rates of total credit growth, exceeding 50\% year-on-year on average along the period (Table 1). This translated to high rates of money supply growth. The interest rates were obviously high but there is no relevant statistic that illustrates them correctly. The currency substitution ("eurization") of the Serbian economy remained extremely high throughout the period. About $70 \%$ of deposits are denominated in foreign currency, while the same percentage of loans is indexed in foreign currency (usually in euro).

\footnotetext{
5 As suggested in Vives (2001): 'Different countries may have different optimal levels of competition intensity. Countries with a strong regulatory structure where risk based insurance and informational disclosure can be implemented to a high degree and with relatively low social costs of failure will benefit from vigorous rivalry. To the contrary, emergent and developing countries' economies with a weak institutional structure and high social costs of failure should moderate the intensity of competition.'
} 
Table 1: Macroeconomic indicators for Serbia (2000-2006)

\begin{tabular}{|c|c|c|c|c|c|c|c|c|}
\hline Year & $\begin{array}{l}\text { Retail prices, } \\
12 \text {-m growth rate }\end{array}$ & $\begin{array}{l}\text { Net Capital } \\
\text { inflows } \\
\text { in } \% \text { of GDP }\end{array}$ & $\operatorname{dinar} \mathrm{M} 2 / \mathrm{GDP}$ & $\mathrm{M} 2 / \mathrm{GDP}$ & $\begin{array}{l}\text { FX to total } \\
\text { deposits }\end{array}$ & $\begin{array}{c}\text { Credit to } \\
\text { enterprises and } \\
\text { households, } \\
\text { y-o-y nominal } \\
\text { growth rate }\end{array}$ & $\begin{array}{c}\text { Credit to } \\
\text { households, } \\
\mathrm{y}-0-\mathrm{y} \text { nominal } \\
\text { growth rate }\end{array}$ & $\begin{array}{c}\text { Credit to } \\
\text { enterprises, } \\
\text { y-o-y nominal } \\
\text { growth rate }\end{array}$ \\
\hline & \multicolumn{8}{|c|}{ in \% } \\
\hline 2000 & 111.90 & 4.21 & 7.61 & 18.36 & 59.53 & n.a & n.a & n.a. \\
\hline 2001 & 40.70 & 8.36 & 8.22 & 17.70 & 57.23 & 23.65 & 71.59 & 21.38 \\
\hline 2003 & 7.80 & 16.69 & 9.09 & 22.37 & 59.45 & 81.08 & 86.19 & 80.37 \\
\hline 2004 & 13.70 & 16.12 & 8.49 & 24.69 & 63.55 & 44.26 & 125.20 & 32.76 \\
\hline 2005 & 17.70 & 18.07 & 13.24 & 28.41 & 65.74 & 51.25 & 98.67 & 39.83 \\
\hline 2006 & 6.60 & 29.55 & 13.31 & 30.03 & 62.35 & 17.50 & 62.20 & 11.10 \\
\hline
\end{tabular}

Source: NBS Statistical bulletin

\subsection{The Schedule of Banking System Reforms in Serbia 2000-2006}

Despite its specific history ${ }^{6}$, the Serbian banking sector followed a similar reform path as other transition countries, resulting in a modern looking banking system like in more advanced transition economies.

Banking reform in Serbia contained the measures typical for transition economies. The Bank Rehabilitation Agency was established in 2001 as a government body charged with handling the 'ill' state owned banks. In January 2002, the Agency decided to liquidate the largest 4 banks from the inherited banking system (Jugobanka, Beogradska banka, Beobanka and Investbanka). The remaining state-owned banks were either merged to larger and healthier ones or remained under surveillance of the Agency until their privatization or definite liquidation. The banking market was opened to foreign bank entry in $2001^{7}$. The first de novo foreign banks were licensed (Raiffeisen, HVB) in 2001.

\footnotetext{
${ }^{6}$ The Serbian banking system reposed on the Yugoslav banking system, which differed from the other centrally planed financial systems of the region. However, after a decade of social and economic decay, Serbia entered 2000 with a banking system that was not only unreformed, but burdened by bad and shameful memories of frozen citizens' foreign currency savings in 1992, historic record hyperinflation (1992-93), and pyramid schemes. These phenomena all manifested the abuse of the banking system for political purposes and reflected in the banks' balance sheets in roughly the following way. On the liabilities side, as EUR 4.2 billion of old 'frozen' foreign currency citizens' savings and respective interests due, about EUR 6.5 billion of liabilities for loans from the Paris and London club of creditors that banks channeled to the economy acting as a primary debtor toward foreign creditors. On the assets side - the bad loans in the same amount were placed mainly in several large state controlled companies, which were able to benefit from such loans for social and political purposes. But besides these, the private sector hardly survived during the $90 \mathrm{~s}$; it relied mainly on self-financing from own accumulation, while citizens relied largely on foreign currency remittances. Although accounting for $200 \%$ of GDP (EUR 12.4 billion) in 2000, the banking system was almost non existent, its 'dead' part representing about $70 \%$ of total banking assets at the end of the 1990s. At the same time, the banking system was highly controlled and artificially concentrated (5 large state controlled banks represented $63 \%$ of banking assets on 31 December 2000 ) and contained too many banks (87 at the end of year 2000) compared to other economies of similar size. Many of the small banks that emerged during the 90s served to satisfy their owners' financing needs and those of their closely related parties. Prudential supervision of banks was very lax throughout the pre-reform period, resulting in a highly under-capitalized, inefficient and unprofitable banking system at the eve of the reforms (see Table 2 for year 2000). The new government (established in October 2000) committed itself to reforming the economy and radical reforms aiming to promote a sound and efficient financial system were undertaken in the banking sector.

${ }^{7}$ In almost all transition economies, except Slovenia, after 10 years of transition it became a dominant type of bank ownership.
} 
The factors common to the sharp credit acceleration in Serbia and in other transition countries $^{8}$ are successful post-crisis macroeconomic stabilization and robust growth, restoration of confidence in the banking sector, and sizable foreign exchange inflows. Loans are financed by the re-entry of cash into the banking system and the revival of deposits. However, the liberalization of the banking market led to increasing foreign bank participation. Their entry was often encouraged by local banking authorities, which faced the difficult task of rehabilitating, recapitalizing and stabilizing the inherited banking sectors. The newly established foreign banks rely on extensible funding from their West-European mother banks (contrary to local banks) ${ }^{9}$. This credit boom provides a field for increased competition in the lending market in transition countries growing from a very shallow basis.

The new central bank representatives committed themselves to a tough and independent prudential supervision of banks since 2001, constantly reinforcing banking regulations in line with internationally recommended principles of banking supervision and practices from developed economies.

The Serbian banking sector has thus dramatically changed between 2000 and 2006. The state-owned banks' share in total banking sector assets dropped from $94 \%$ in 2000 to only $15 \%$ at the end of 2006, while foreign banks (representing $0 \%$ in 2000) attained $79 \%$ of total assets (Table 2). The size of the banking sector measured as total assets to GDP (column 3 in Table 2) increased from $35 \%$ in 2002 to almost $65 \%$ in 2005 , indicating still a low level of financial intermediation. The concentration of the banking system did not decrease significantly with the entry of new banks. The index of concentration $\mathrm{C} 5$ (the share of 5 biggest banks in total banking assets) reached almost $50 \%$ by the end of 2006 . The overall bank performance improved due to improved supervision and competition, as well as the improving business environment. ROA has thus evolved from $-33 \%$ in 2001 to $1.7 \%$ in 2006 (column 7, Table 2).

Table 2: Banking sector indicators

\begin{tabular}{|c|c|c|c|c|c|c|c|c|}
\hline Year & Total assets & $\begin{array}{l}\text { Total assets, } \\
\text { in } \% \text { of GDP }\end{array}$ & $\begin{array}{c}\text { Loans to } \\
\text { enterprises and } \\
\text { households, } \\
\text { in } \% \text { of GDP }\end{array}$ & $\begin{array}{c}\text { Foreign bank } \\
\text { owned assets to } \\
\text { total banking } \\
\text { assets }\end{array}$ & $\begin{array}{c}\text { State-owned assets } \\
\text { to total banking } \\
\text { assets }\end{array}$ & ROA & $\begin{array}{c}\text { C5 concentration } \\
\text { indeks }\end{array}$ & $\begin{array}{c}\text { Bad assest (C, D } \\
\text { and E) in total } \\
\text { classified assets }\end{array}$ \\
\hline \multirow[t]{2}{*}{1} & 2 & 3 & 4 & 5 & 6 & 7 & 8 & 9 \\
\hline & in EUR millions & & & & in $\%$ & & & \\
\hline 2000 & 12433 & 205.42 & 119.11 & 0.00 & 94.23 & -5.95 & 63.12 & n.a. \\
\hline 2001 & 12520 & 105.52 & 56.53 & 2.80 & 88.06 & -32.54 & 62.76 & n.a. \\
\hline 2002 & 5363 & 35.93 & 19.75 & 14.21 & 60.14 & -8.05 & 45.26 & 24.30 \\
\hline 2003 & 5339 & 33.38 & 17.67 & 22.96 & 50.09 & -0.27 & 47.88 & 22.49 \\
\hline 2004 & 6450 & 38.93 & 22.19 & 37.65 & 37.37 & -1.41 & 47.30 & 23.31 \\
\hline 2005 & 9069 & 47.93 & 26.37 & 67.06 & 25.06 & -0.47 & 50.27 & 23.17 \\
\hline 2006 & 16130 & 64.82 & 30.98 & 78.70 & 14.80 & 1.70 & 47.20 & n.a. \\
\hline
\end{tabular}

Source: NBS Statistical bulletin and own calculations for columns from (1) to (8), NBS Banking system reports for column (9)

\section{The main features of the newly establishing banking sector}

As recorded in balance sheets of banks

\footnotetext{
${ }^{8}$ See for example Duenwald et al. 2005 for an analysis of credit booms in Bulgaria, Romania and Ukraine. ${ }^{9}$ As stated in Duenwald et al. 2005, pp. 13 for the cases of Bulgaria, Romania and Ukraine: "Many of the banks' foreign owners are domiciled in less profitable mature markets, so parents have encouraged their subsidiaries and branches to pursue aggressive loan portfolio expansion to gain market share and improve consolidation results, thereby contributing to the acceleration of credit."
} 
As proven by various studies of transition banking sectors, ownership was a crucial factor for differentiation among banks, or at least the one factor that can be attributed to differences in principal performance and asset structure ratios. This trend was present in Serbia as well. Ownership (measured as foreign bank owned, state-owned and domestic private bank) played a more significant role in the differentiation of the liabilities structure (structure of resources of financing) than it does on the assets side of balance sheets, i.e. the structure of placements and asset holdings (see Appendix IV).

On the liabilities side, locally owned private banks enjoy financing mainly from capital (high equity to debt ratios), as well as from enterprises deposits. They also have a lower share of collected foreign currency savings from households compared to the two other ownership categories. Foreign bank funding is significantly dominated by loans and deposits they receive from abroad (parent companies), which is not at all the case with the other two ownership categories. They also have an important share of the newly collected citizen's foreign currency savings, which experienced a revival and face a constantly increasing trend since the reforms were launched at the end of 2000. The heterogeneity in the liabilities structure is likely to have an impact on bank strategies, since it affects the availability of long term funding, liquidity, or costs. Banks still do not refinance them by issuing bonds or bills since the financial markets are not developed enough. The inter-bank liquidity market is active but there is still very little information about its functioning.

On the asset side, domestic private banks extend relatively fewer loans to citizens compared to their total assets than other bank types. All banks hold a high share of cash and cash equivalents in their assets. Lending represents the core banking activity ${ }^{10}$ so that interest and fees are the principal components of bank income. Almost all observed banks operate as universal banks on the whole territory. There are a few banks that focus on a certain region, but they still operate as universal banks. There is one specialized bank (JUBMES) for supporting the export of priority goods, and we exclude it from our sample in further empirical estimations.

\section{As surveyed by on-site interviews}

In addition to the common problems encountered by banks in early transition, such as insufficient creditor rights protection and lack of good collaterals, our on-site banking survey ${ }^{11}$ registered several interesting features that provide some indications and deeper insight in the lending market structure hardly observable trough official balance sheet data. Namely, two particular findings - on interest rates and barriers to further credit expansion indicate the existence of certain segmentation on the lending market.

We observe, as shown in Table 3 , the large diversity of prevailing interest rates across banks for the same loan type with same maturity and purpose. For instance, a 12-month loan for current assets to large enterprises carries interest rates ranging from $7 \%$ to $21 \%$ p.a., depending on the bank. The dispersion of interest rates is greater with short term than with

\footnotetext{
${ }^{10}$ The banks operate on the securities market as well, but these activities are of limited scope since the equity market remains underdeveloped during the whole period.

${ }^{11}$ Since the central bank statistics did not consistently follow the interest rates, the aim of the Survey was initially to document the interest rates in Serbian banks - both lending rates and deposit rates - and to describe their main determinants. For a detailed report on the survey, see Quarterly Monitor issued No.2 by FREN, www.fren.org.yu
} 
long term loans. These findings suggest the existence of some segmentation in the credit market. It is likely that some banks are more present in a certain risk category of clients. Competitive forces therefore do not affect a bank's interest rates in the same manner in the segment of large borrowers with a wide and good reputation as in the segment of locally operating smaller enterprises with opaque official financial information (practices of enterprises' parallel accounting) but with a deep and long-lasting relationship with a bank.

Yet, the survey also showed the presence of competition among banks. In spite of restrictive monetary conditions which were present in Serbia in the period of the survey, ${ }^{12}$ the pattern of banks' answers to the question on the evolution of lending interest rates ${ }^{13}$ indicates the following: the majority of interviewed banks lowered their rates despite being increasingly burdened by restrictive measures of the central bank. Thus we conclude that the banking sector gets more competitive in the observed period. The competition might be more pronounced on a certain segment of the lending market, since, as shown in Table 4, there are some banks not affected by the competitive pressures.

Table 3: Prevailing Effective Interest Rate ${ }^{1)}$ on New Lending (Aug-Oct 2005)

\begin{tabular}{|c|c|c|c|c|c|}
\hline \multirow[b]{2}{*}{ Type of client / loan } & \multirow{2}{*}{$\begin{array}{l}\text { foreign } \\
\text { currency } \\
\text { clause }^{2)}\end{array}$} & \multirow[b]{2}{*}{ no. of answers } & \multicolumn{3}{|c|}{ Prevailing rate in banks } \\
\hline & & & minimum & average $^{3)}$ & maximum $^{4}$ \\
\hline \multicolumn{6}{|l|}{ Loans to large enterprises } \\
\hline 12-month loans for current assets & yes & 8 & 7.00 & 9.21 & 22.00 \\
\hline 12-month loans for current assets & no & 3 & 21.05 & 23.37 & 25.00 \\
\hline 5-year investment loans & yes & 7 & 6.00 & 9.10 & 10.40 \\
\hline \multicolumn{6}{|l|}{ Loans to SME's } \\
\hline 12-month loans for current assets & yes & 12 & 9.00 & 14.53 & 35.87 \\
\hline 5-year investment loans & yes & 11 & 7.50 & 9.43 & 12.30 \\
\hline \multicolumn{6}{|l|}{ Loans to households } \\
\hline Unauthorized overdrafts on current accounts & no & 16 & 24.00 & 52.50 & 103.00 \\
\hline Authorized overdrafts on current accounts & no & 11 & 14.33 & 41.48 & 48.15 \\
\hline 3-36 month consumer and cash loans & yes & 15 & 11.00 & 15.82 & 28.66 \\
\hline 10-year mortgage loans & yes & 9 & 6.89 & 10.01 & 14.41 \\
\hline
\end{tabular}

Source: FREN's questionnaire on interest rates, Aug-Oct 2005

1) All interest rates are given on annual level in a form of nominal rates. Inflation rate September 2005 to September 2004 was $16.5 \%$, in Euro-zone around $2 \%$, annualised exchange rate (dinar/euro) index for the same period was 113.6 . The prevailing interest rate refers to the rate offered in most of the loan contracts with one bank.

2) The existence of foreign currency clause in a loan contract mean that loan is indexed to a foreign currency (mostly to the euro). In order to avoid problem of averaging two fundamentally different categories of interest rates (on indexed loans and on not indexed loans) for the same loan type, we split the question by the indexation criteria. This column specifies whether the loan is indexed.

3) Weighted with share of loans to the borrowers category (large enterprises, SMEs, households) in total loans to the borrowers category of surveyed banks, on June 30, 2005

4) Loans to large enterprises - second scanned maximum. The first maximum is excluded because the bank rarely grants the loans to large enterprises and it is focused on various clients.

\footnotetext{
${ }^{12}$ Monetary policy was very restrictive in order to slow down inflationary pressures. Aiming to make the banks' sources of funds more expensive, the central bank was increasing the statutory reserve requirements on deposits and received short term loans, and it sterilized liquidity trough repo contracts with attractive interest rates.

${ }^{13}$ The questions asked in the survey were whether and how often the interest rates changed, and what the nature of revised decisions on lending rates was in the first half of 2005. With retail lending, in 15 out of 19 banks which answered these questions, the revised decision on interest rates related to the decline of their general level. Only in one case, the retail lending rates increased. With lending to enterprises, 8 out of 17 banks made decisions to reduce interest rates, while one third of the changes related to the altered elements included in the final interest rate.
} 
Table 4. Competitive pressure and its effects on lending terms ${ }^{1)}$

\begin{tabular}{|c|c|c|c|c|c|c|c|}
\hline & & \multicolumn{3}{|c|}{ Credits to enterprises ${ }^{2)}$} & \multicolumn{3}{|c|}{ Credits to households ${ }^{2)}$} \\
\hline & & interest & $\begin{array}{c}\text { additional } \\
\text { charges }\end{array}$ & $\begin{array}{c}\text { non-price } \\
\text { lending terms }\end{array}$ & interest & $\begin{array}{c}\text { additional } \\
\text { charges }\end{array}$ & $\begin{array}{c}\text { on-price } \\
\text { lending terms }\end{array}$ \\
\hline 1 & Competitive pressures affect the loan conditions in our bank & 12 & 9 & 7 & 15 & 11 & 8 \\
\hline 2 & We feel competitive pressure, but we have no room to change our lending terms & 1 & 1 & 1 & 0 & 2 & 0 \\
\hline 3 & $\begin{array}{l}\text { We feel the pressure by competition but we do not change our lending terms as we have other ways to } \\
\text { adjust. }\end{array}$ & 5 & 6 & 5 & 2 & 2 & 2 \\
\hline 4 & Competitive pressures do not affect loan conditions in our bank & 1 & 1 & 3 & 1 & 1 & 4 \\
\hline
\end{tabular}

Source: FREN's questionnaire on interest rates, Aug-Oct 2005.

1) For each lending term aspect (interest rates, additional charges and non-price lending terms) banks were asked to select one of the four given answers.

2) All 19 surveyed banks answered

Our field survey also found that the main obstacle for further credit expansion toward enterprises was the lack of collateral means and the lack of screened profitable projects, which is specially the case in the answers of foreign-owned banks. On the other hand, for domestically owned banks, the lack of funding and regulatory barriers seem to be key. The finding indicates that there are segments on the market, and that some banks are not present in all segments in the same manner, i.e. while certain banks would ration some clients, other banks would grant them a loan.

Table 5. Key Barriers to Further Credit Expansion in the First Half of 2005

\begin{tabular}{|c|c|c|c|c|c|c|c|c|}
\hline & \multicolumn{4}{|c|}{ credits to enterprises ${ }^{1)}$} & \multicolumn{4}{|c|}{ credits to households ${ }^{2)}$} \\
\hline & $\begin{array}{l}\text { foreign owned } \\
\text { banks }\end{array}$ & state owned banks & $\begin{array}{l}\text { other private } \\
\text { banks }\end{array}$ & total & $\begin{array}{l}\text { foreign owned } \\
\text { banks }\end{array}$ & state owned banks & $\begin{array}{l}\text { other private } \\
\text { banks }\end{array}$ & total \\
\hline Lack of funding & 1 & 2 & 0 & 3 & 0 & 2 & 1 & 3 \\
\hline Lack of bankable projects & 3 & 1 & 0 & 4 & 1 & 1 & 0 & 2 \\
\hline Means of securing credit & 5 & 1 & 1 & 7 & 2 & 0 & 0 & 2 \\
\hline Regulatory barriers & 1 & 0 & 2 & 3 & 3 & 0 & 1 & 4 \\
\hline Other & 0 & 0 & 0 & 0 & 0 & 0 & 0 & 0 \\
\hline
\end{tabular}

Source: FREN's questionnaire on interest rates, Aug-Oct 2005.

1) 13 banks answered.

2) 11 banks answered.

\section{THEORETICAL FRAMEWORK, DATASET, VARIABLES DEFINITION AND EMPIRICAL METHODOLOGY}

The previously presented findings from the field survey lead us to proceed with an empirical analysis of the banking dataset in order to explain the underlying mechanism that forms some sort of competition among banks but results in such dispersed lending interest rates. As a possible explanation could lay in the concentration of market power (higher margins) and/or concentration of risks across different banks, both scenarios indicate a segmentation of the lending market, we essentially seek to explain the sources of such segmentation. We proceed in the following logical sequence along this empirical part of the paper: first we identify the existence of differential in banking spreads between ownership categories of banks, and we further test the existence of incidence of increasing foreign bank presence on average bank asset quality.

The reasoning about the structure of the lending market in Serbia in its post liberalization phase, which is, despite the presence of competition, characterised by extremely dispersed lending interest rates, lies in line with the theoretical framework of dell'Ariccia and 
Marquez (2005) for liberalized banking markets with foreign bank entry and competition between foreign and domestic banks.

Information has a key role in shaping the lending market structure, which results in a certain level of market segmentation. The competition for borrowers between a lender with an informational advantage (local banks) and an outside lender (foreign-bank owned banks) with less information, but with a cost advantage (due to access to cheaper refinancing from its mother institutions based in developed markets), creates market segmentation in the following manner: having less information about local borrowers, foreign new entrants focus their lending on the more transparent market segment which is then the more competitive one. Foreign banks charge lower spreads, and the quality of their assets is on average higher relative to domestic incumbent banks. On the other hand, the model shows that when faced with greater competition from outside lenders; 'informed' domestic banks shift their credit towards the sector where their competitors face greater adverse selection problems. They refer this reallocation as a 'flight to captivity'. In these, less competitive market segments, spreads are higher, demonstrating certain market power of banks toward their less transparent and consequently more captive clients. The model demonstrates that, as a consequence, the average quality of borrowers obtaining financing from the informed lender is decreasing in its informational advantage, when a negative correlation between borrower quality and degree of information asymmetry is strong enough. Hence, there are compositional differences in banks' portfolios across market segments characterized by different degrees of asymmetric information about borrowers.

On the Serbian example, foreign banks tend to be more present on the market of internationally known corporations and well known large enterprises. These banks are in a position to charge lower spreads and to offer lower interest rates than their local counterparts, enjoying extensive refinancing from their mother banks in order to attract these borrowers. Domestic banks, in light of the model, are likely to remain more present in lending to less transparent but more 'captive' borrowers with which they have long lasting relationships, so they are in a better position to evaluate their projects as creditworthy even though the available information would not show the same level of attractiveness. Since on this market, domestic banks do not face foreign competition, they are in a position to charge relatively higher spreads than is the case with the more transparent segment of clients. Hence, their portfolio is likely to deteriorate in average quality (i.e. in information, correlated with the quality i.e. 'apparent' quality) with increased presence of foreign banks. This is represented in a schematic way in a Figure 1, at the end of this article. In empirical estimations that follow, we seek to verify the existence of market segmentation due to the competition between two ownership categories of banks.

We first present our dataset. Then, we give the underlying theoretical framework for our empirical analysis used for the choice of certain variables for our analysis and for the specification of the estimated model. Third, we present the specification of the estimated model. Then we define all employed variables and comment on their descriptive statistics. We emphasize the indicator of asset quality since, unlike other variables widely used in the literature for describing identical features, we use an already exploited variable of provisions for risky assets to total assets - we name it as elsewhere (asset quality), but we interpret it in a somewhat modified way.

\subsection{Dataset}


Our dataset is composed of individual bank data covering the entire Serbian banking sector. Individual bank data consist of annual detailed financial statements (balance sheet and profit and loss account). This database was created thanks to the National Bank of Serbia, which provided the detailed content of banks' accounts that enter the official financial statements. We use data for the period 2001-2005 for all licensed banks. Unlike most studies based on a degree of coverage of a banking system with data available from the BankScope database, our dataset covers $100 \%$ of the banking system. The majority of empirical conclusions on bank performance in transition economies are based on data from the BankScope database, which potentially suffer from a serious composition bias towards large banks $^{14}$. According to our knowledge, there is no previous study of one banking system in transition as a whole, based on micro level financial data. However, as some banks have been closed, and others obtained licenses or took over/merged with another bank during the observed period, we have to deal with an unbalanced panel dataset. At the same time, some banks officially having a license have been inactive, so that we were obliged to exclude them from our sample and estimations (by treating them as 'quasi-operating'). The criteria for treating a bank as quasi-operating were the following: no change in accounting data compared to the previous year; zero balance of accounts such as cash or reserves with the central bank and officially revoked license the following year; financial statements obviously show that the bank has no credit activity in the respective year; no increase in the balance of loans to nonfinancial sector and zero expenses for provisions for risks.

This dataset is also unique due to the fact that it takes into account the change in accounting methodology and the modification of the official presentation for banks' financial statements in Serbia in the course of the observed period (between 2002 and 2003). Namely, the official map of accounts ${ }^{15}$ and the official scheme of annual financial statements ${ }^{16}$ have been modified. In order to obtain a comparable series of data, we mapped the accounts across two different regulatory frameworks. This was possible due to the availability of the detailed content of specific items in the balance sheets and profit and loss accounts. We believe that our final dataset has the most coherent and methodologically proper content that was possible to attain, taking into account all sources of distortions that were present and that we have been aware of ${ }^{17}$.

We dispose of 218 observations (quasi-operating banks excluded) for the period (2001-2005) which refers to a sample of 81 different banks. The distribution of observations across years and bank types is given in Table 6.

Table 6: Distribution of observation across bank types

\footnotetext{
${ }^{14}$ Ehrmann et al. (2003) estimate the effects of monetary policy across banks on both BankScope (commercial database with a partial coverage of national banking systems) and Eurosystem data (covering full population of banks in a country, collected by national central banks) in four large countries of euro area. They find significantly different results on BankScope data with incomplete coverage.

${ }^{15}$ National bank of Serbia, Rules on the chart of accounts and content of accounts within the chart for banks and other financial organisations

${ }^{16}$ National bank of Serbia, Rules on forms and content of individual items in financial statement forms to be completed by banks and other financial organizations

${ }^{17}$ This kind of distortion is common for all transition economies, representing a serious obstacle for quantitative analyses of these economies. However, we have not found a discussion dedicated to this methodological issue in any studies analyzing banking systems based on banks' accounting data.
} 


\begin{tabular}{cccccc}
\hline & \multicolumn{3}{c}{ Bank type by ownership } & & \\
\cline { 2 - 3 } Year & State owned & Domestic private Foreign owned & Total & \% of total \\
\hline & & & 5 & $\mathbf{5 2}$ & $24 \%$ \\
2001 & 27 & 20 & 7 & $\mathbf{4 5}$ & $21 \%$ \\
2002 & 19 & 19 & 11 & $\mathbf{4 2}$ & $19 \%$ \\
2003 & 16 & 15 & 11 & $\mathbf{4 1}$ & $19 \%$ \\
2004 & 15 & 15 & 18 & $\mathbf{3 8}$ & $17 \%$ \\
2005 & 12 & 8 & $\mathbf{5 2}$ & $\mathbf{2 1 8}$ & $100 \%$ \\
Total & $\mathbf{8 9}$ & $\mathbf{7 7}$ & $\mathbf{2 4 \%}$ & $100 \%$ & \\
\% of total & $41 \%$ & $35 \%$ & & &
\end{tabular}

Source: Author's calculations

\subsection{Estimation Specification}

We estimate two separate regressions in order to analyze the structure of the lending market.

\section{(1) Banking spreads}

This estimation aims to allow an analysis of the determinants of bank market power, paying special attention to the effect of bank ownership. We use the banks' Net interest margin as the dependent variable (also called 'spread' in some literature). The model specification is motivated by two existing frameworks already explored in relevant literature. We apply the dealership approach ${ }^{18}$ and the firm-based theoretical framework ${ }^{19}$ for estimation specification.

The estimated model for bank interest margin has the following form:

$$
\begin{aligned}
& \text { Net_interest_margin }{ }_{i, t}=\alpha_{0}+\alpha_{1} \text { Administrative_costs }_{i, t}+\alpha_{2} \text { Funding_cost }_{i, t}+ \\
& \alpha_{3} \text { Equity }_{i, t}+\alpha_{4} \text { Market_share }_{i, t}+\alpha_{5} \text { Short_term_loans }_{i, t}+\alpha_{6} \text { Enterprise_loans }_{i, t}+ \\
& \alpha_{7} \text { Foreign_bank_share }_{t}+\alpha_{8} \text { Foreign_bank }_{i, t}+\alpha_{9} \text { State_owned_bank }_{i, t}+ \\
& \alpha_{10} \text { Merged }_{i, t}+\alpha_{11} \mathrm{D} 2001_{t}+\varepsilon_{i, t}
\end{aligned}
$$

where $i$ is a bank and $t$ refers to the time period considered.

$$
\text { Asset quality: information }
$$

This estimation aims to further analyze the determinants of bank asset quality since the presented theoretical framework (dell' Ariccia and Marquez, 2003) suggests that high spreads are occurring in markets subject to large information asymmetry. An important implication of this result is that the average quality of borrowers obtaining financing from the informed lender is decreasing in its informational advantage. Thus, the analysis of asset quality as the dependent variable in light of ownership differences among banks makes sense in this paper.

\footnotetext{
${ }^{18}$ The dealership approach for analysis of banks is developed by Ho and Saunders (1981), extended by Allen (1988). The dealership approach is particularly convenient for analyzing bank spreads in the Serbian case, since most bank activities consist of credit granting and deposit taking (the securities business is very poorly developed, as well as services), just as it the model assumes.

${ }^{19}$ Firm-theoretical framework uses micro-model of banking firm, based on the approach of Klein (1971) and Monti (1972) and extended by Zarruck (1989) and Wong (1997)
} 
We use the ratio of provisions for bad assets to total earnings assets as a proxy for bank asset quality so that higher value of the variable means lower asset quality. It is calculated based on accounting information on bank clients as prescribed by the criteria set by the central bank ${ }^{20}$. These criteria are presented in synthetic form in Appendix I. They basically attempt to capture the risk of the borrower. However, due to the many peculiarities of a transition economy, it is very likely that a borrower which is classified in a riskier category by the application of the prescribed criteria and according to the apparent characteristics of the borrower (hard information based on accounting), may, in reality and from the point of view of an informed bank that has a long lasting relationship with the client, actually not bear a risk - and that soft information suggests that the borrower is creditworthy for his bank. In practice, it is possible that the abovementioned 'classification' of assets prescribed by the regulatory authority: a) does not cover all objective determinants of credit risk in Serbia, b) covers through its criteria some theoretically correct risk determinants, but which do not represent an objective risk for Serbian banks ${ }^{21}$. Thus, we consider it more convenient to interpret the variable Asset quality as the apparent quality of the borrower (the quality observable by any bank). This interpretation contains an element of information asymmetry. Borrowers classified in a riskier category (C, D or E, see Appendix I) are then subject to higher provisions for the bank as provisions are regulated and based on available accounting information (profit and loss, cash flows). Taking into account these criteria, we do not deny that there is a strong correlation between the poor image obtained about the client based on this information and its credit risk. The correlation is, in our opinion, not complete since, being regulated, the criteria for provisions do not take into account some soft information that could mitigate if not completely negate the image based on hard information, and captured by the Asset quality variable. This interpretation is well captured by the framework of another theoretical model developed by Detragiache et al. (2006), where banks are supposed to screen two types of information from clients: hard information and soft information. In their theoretical model, foreign banks are better than domestic banks at monitoring "hard" information, such as accounting information or collateral values, but not at monitoring "soft" information, such as the borrower's entrepreneurial ability or trustworthiness

The estimated model for bank asset quality is based on our intuitive choice of RHS variables with the idea to include all reasonably possible factors measurable with the available dataset that can influence asset quality, but excluding everything that could cause a seriously biased estimation parameters due to endogeneity or multicollinearity between variables. The model has the following form:

$$
\begin{aligned}
& \text { Asset_quality }{ }_{i, t}=\alpha_{0}+\alpha_{1} \text { Equity }_{i, t}+\alpha_{2} \text { Adiministrative_cost }_{i, t}+ \\
& \alpha_{3} \text { Market_share }_{i, t}+\alpha_{4} \text { Liquidity }_{i, t}+\alpha_{5} \text { Enterprise_loans }+ \\
& \alpha_{6} \text { Short_term_loans }+\alpha_{7} \text { Foreign_bank_share }_{t}+\alpha_{8} \text { Foreign_bank }_{i, t}+ \\
& \alpha_{9} \text { State_owned_bank }{ }_{i, t}+\alpha_{10} \text { Merged }+\alpha_{11} \mathrm{D} 2001_{t}+\varepsilon_{i, t}
\end{aligned}
$$

\footnotetext{
${ }^{20}$ Decision on Criteria for the Classification of Balance Sheet and Off-balance Sheet Items According to the Level of Collectability and Special Provisions of Banks and Other Financial Organisations (RS Official Gazzette, No. 37/2004, 86/2004 and 51/2005)

${ }^{21}$ For use and misuse of the aggregate measure of non performing loans for the whole country by classification of assets in risk categories according to the prescribed criteria, and it comparison to aggregate measure of overdue loans for 90 days and more, see Dimitrijevic J. (2006)
} 
where $i$ is a bank and $t$ refers to the time period considered.

\subsection{Definition of Variables}

The definition of variables ${ }^{22}$ is largely drawn from literature ${ }^{23}$. In Equation (1), the variable Net interest margin is calculated as interest income minus interest expense over total bank earnings assets that the income and expense refer to. Some studies use this ratio as a measure of the efficiency of financial intermediation. We consider that the latter holds on the aggregate level for the entire banking system. On the individual bank level, however, a higher spread charged by a bank to some clients rather represents an indicator of the bank's market power, controlling for all other factors (asset and liabilities structure, administrative costs and funding costs).

In the equation (1), we control for capitalization calculated as the ratio of equity over total assets (variable Equity) on RHS, since we do not dispose of a unique implicit cost of capital necessary to have appropriate comparable values of market power (a markup pricing approach). Different levels of financing trough own capital have an impact on spread, so that this variable serves for controlling the spread differences among banks due to the construction of the spread variable (interest income minus interest expenses on deposits, but not taking the cost of equity into account). We do not interpret capitalization as a solvency measure, since there are some specific features of transition banking where a capital market is neither developed nor efficient, so that the capitalization ratio is ambiguous. For example, in some cases a higher capital to asset ratio is a sign of a sound bank, but a very high capital to asset ratio could equally be a sign that the bank is not active since is not able to attract enough deposits and/or serves its founders for some other activities. At the same time, this ratio can in some cases be differently influenced by regulations across different types of banks (for example: increase in the rate of compulsory reserve requirement on deposits from abroad received by foreign owned banks from their mother institutions resulted in an increase in the capital of these banks in order to circumvent this regulatory requirement). Funding costs is a variable measuring the average interest rate that the bank pays for its funding (collected deposits and received loans). It is calculated as the ratio of accrued interest expense to total bank's debt. Market share, a proxy for bank size, is measured by the bank's participation in the total assets of the banking sector. Administrative costs is the ratio of operating expenses over assets. This variable intends to capture the operational efficiency of a bank as well as monitoring costs. Enterprise loans capture the share that loans given to enterprises in total assets of a bank. The variable Short term loans is an indicator of the share of loans with maturity up to one year in a bank's total loans. We are interested in the effect of this ratio on banking margins since our field survey observed a significantly higher dispersion of interest rates in short-term loans (relative to long-term ones) across banks for all types of borrowers. Thus our aim is to verify whether banks exert higher market power with short term lending.

\footnotetext{
${ }^{22}$ In Appendix III, we present all variables as they are calculated and descriptive statistics for all banks, as well as by different ownership categories.

${ }^{23}$ See for example: Vittas, D. (1991) 'Measuring Commercial Bank Efficiency, Use and Misuse of Bank Operating Ratios', IMF WPS; and also Financial Sector Assessment: A Handbook, IMF/the World bank, September 2005; and Compilation Guide on Financial Soundness Indicators, IMF, 2003 for detailed issues to be considered in the use of different measures of bank performance.
} 
Foreign bank is an 'ownership' dummy variable which equals 1 for banks owned by a foreign bank. State owned bank is a dummy for state-owned banks. The criterion for coding ownership as foreign, state or domestic private is the following: we consider a bank as majority owned by a foreign bank, the state, or a private domestic owner if it has more than $50 \%$ of capital in possession of one ownership type. The variable Merged is a dummy that equals 1 for a bank that was taken over by another bank or merged with another bank, for the year when the takeover took place and for all previous years. This variable aims basically to control for the potential bias which would result from specificities of banks that are 'candidates' for a takeover, i.e. from the performance specificities of remaining banks. D2001 is a dummy variable for the first year of economic reforms (2001), when most restructuring and new regulations concerning the banking sector took place.

Foreign bank share is the share of loans in the hands of foreign banks in the whole banking system at the end of each year in the period of interest.

\section{ESTIMATION RESULTS}

We run in parallel OLS, GLS or fixed effect estimators in the set of regressions. We only partly control for the attrition problem of our panel dataset (see Table 6), by introducing the variable Merged in order to capture the effect that some banks ceased their operation by being taken over by another bank. We find an interesting set of observations that follows.

\subsection{Net Interest Margin: Market Power}

Using the entire population of banks, we observe the determinants of banks' margins. We estimate a panel GLS regression and OLS regression, presented in Table 7.

The most interesting finding in this estimation is that, after controlling for the impact of various costs, the structure of assets, and bank's market share, we do find that ownership matters for bank interest margin. Foreign banks, on average, charge lower margins over the cost of funding than their domestic counterparts. State ownership, however, does not have a significant impact on the charged margins of domestic banks.

The variable Foreign bank presence does not influence interest rate margins. One factor could explain the fact that domestic banks' margins do not reduce due to the presence of foreign competitors. Foreign banks attract higher quality clients (or at least those with a better reputation, i.e. more transparent information), and they offer them lower interest rates. Domestic banks' portfolios are likely then to remain with more obscure clients, which are not necessarily of lower quality, but do not have a strong reputation, i.e. have more opaque information about their business. Instead, local banks maintain longer relationships with such clients and have a better insight in their risk. This gap between foreign and domestic banks in terms of spread may well characterize the Serbian lending market segmentation as suggested by the theoretical model (Dell'Ariccia and Marquez (2004)) where this segmentation is driven by difference in funding costs across ownership categories ${ }^{24}$. Another explanation for the fact that foreign bank presence (variable foreign bank share) does not have a significant effect on margins on the whole banking system is proposed by Peria Soledad Martinez and Mody (2004) in their study of the determinants of bank spreads in Latin America. The latter result

\footnotetext{
${ }^{24}$ A simple t-test on funding cost differences over ownership categories shows a statistical significance at $1 \%$-with higher funding costs for domestic banks.
} 
that they also obtain does not necessarily mean for them that foreign bank presence does not introduce stronger competition resulting in a reduction of interest margins, but that a 'spillover' effect of foreign bank presence on local banks' spreads occurs probably trough administrative cost reductions.

We also registered the impact of competition on bank interest rates trough the on-site banking survey (Table 4). At the same time, household lending terms were more subject to the competition than the terms of lending to enterprises in the period under consideration. Competitive pressures, however, do not equally affect all respondent banks. Some banks appeared not concerned by competition at all.

Both findings - from the estimation and the on-site survey - show that enterprises seam to be relatively more tied to banks then household, since loans to enterprises are less subject to competition and lead to higher margins. Information asymmetry could be a possible explanation, since it is likely to be more pronounced between enterprises and banks than between households and banks. Many firms in early transition are not in a position to choose the terms of loans, but rely on a bank that follows their operations and has better inside information. These firms are not necessarily of dubious quality, but the official information in their accounting data does not attract other banks' financing. Relationship lending is one way of resolving this and is associated with higher spreads on loans.

Banks with short term lending more represented in their loan portfolios are able to realize higher margins. This finding is consistent with our survey results reported in Table 3 , where short term lending interest rates is more volatile across banks.

Not surprisingly, banks with a greater market share are able to charge higher spreads according to our results. Bank size is likely to be a source of certain market power.

After controlling for differences in capitalization ratios (Equity variable) for reasons we discussed in Section 4, we are interested in controlling for differences in Funding costs. The effect of this variable is not significant ${ }^{25}$. We should, however, keep it in our regression in order to eliminate any effect on spreads arising from funding costs, and thus be sure that the higher spread is not due to the lower interest rates paid on banks' funding (since competition on the deposit market is not the subject of this paper), but that it comes from the higher interest rate charged on loans, all other factors being constant.

Administrative costs have a positive and significant impact on bank margins. Banks with higher administrative costs have more market power in a specific market segment, where it is plausible that they are able to maintain a certain level of spread.

\footnotetext{
${ }^{25}$ This means that there is probably no need for concern about the endogeneity problem here.
} 
Table 7. Estimation results for interest margin

\begin{tabular}{|c|c|c|}
\hline & GLS (random effects) & OLS \\
\hline Variable & $(1)$ & $(2)$ \\
\hline Administrative costs & $\begin{array}{l}0.441 \\
(5.87) * * *\end{array}$ & $\begin{array}{l}0.324 \\
(4.99) * * *\end{array}$ \\
\hline Funding cost & $\begin{array}{l}-0.153 \\
(-1.88) *\end{array}$ & $\begin{array}{l}-0.122 \\
(-0.83)\end{array}$ \\
\hline Equity (over assets) & $\begin{array}{l}0.057 \\
(4.26) * * *\end{array}$ & $\begin{array}{l}0.068 \\
(4.01) * * *\end{array}$ \\
\hline Market share & $\begin{array}{l}0.156 \\
(1.90) *\end{array}$ & $\begin{array}{l}0.159 \\
(2.37) * *\end{array}$ \\
\hline Short term loans & $\begin{array}{l}0.032 \\
(3.02) * * *\end{array}$ & $\begin{array}{l}0.041 \\
(4.27) * * *\end{array}$ \\
\hline Enterprise loans & $\begin{array}{l}0.036 \\
(3.53) * * *\end{array}$ & $\begin{array}{l}0.029 \\
(2.49) * *\end{array}$ \\
\hline Foreign bank share & $\begin{array}{l}0.009 \\
(1.00)\end{array}$ & $\begin{array}{l}0.016 \\
(1.51)\end{array}$ \\
\hline Foreign bank & $\begin{array}{l}-0.020 \\
(-2.91) * * *\end{array}$ & $\begin{array}{l}-0.023 \\
(-4.23) * * *\end{array}$ \\
\hline State-owned bank & $\begin{array}{l}0.000 \\
(-0.02)\end{array}$ & $\begin{array}{l}-0.003 \\
(-0.54)\end{array}$ \\
\hline Merged & $\begin{array}{l}0.008 \\
(0.84)\end{array}$ & $\begin{array}{l}0.007 \\
(1.07)\end{array}$ \\
\hline D2001 & $\begin{array}{l}0.016 \\
(2.72) * * *\end{array}$ & $\begin{array}{l}0.014 \\
(1.73) *\end{array}$ \\
\hline Constant & $\begin{array}{l}-0.029 \\
(-0.03) * *\end{array}$ & $\begin{array}{l}-0.027 \\
(-1.85) *\end{array}$ \\
\hline $\begin{array}{l}\text { Observations } \\
\text { R-squared }\end{array}$ & $\begin{array}{l}218 \\
0.5349\end{array}$ & $\begin{array}{l}218 \\
0.5521\end{array}$ \\
\hline $\begin{array}{l}\text { F-test, individual effects }=0 \text {, } p \text {-value } \\
\text { Hausman specification test, } p \text {-value }\end{array}$ & $\begin{array}{l}0,0000 \\
0.2228\end{array}$ & \\
\hline
\end{tabular}

Notes: t-statistics are in parentheses; *significant at $10 \%$; **significant at $5 \%{ }^{* * *}$ significant at $1 \%$ 
Once we identified the difference in interest margins due to the ownership of banks, and knowing that there is a difference in funding costs in favor of foreign, we proceed now to the estimation of asset quality. It will allow us to obtain the as complete a picture of the lending market structure as possible.

\subsection{Asset quality: measured by "hard" information}

Foreign banks have higher asset quality measured as a ratio of provisions for bad assets over total earning assets than domestic banks (estimation 1 and 2, Table 8). As we already argued that the variable Asset quality captures the quality of hard information about bank borrowers, this finding is in line with the proposed explanation of market segmentation, resulting in the fact that new entering banks, faced with asymmetric information, are more inclined to the segment of transparent borrowers. The usual argument that foreign banks have better risk management practices resulting in lower overall credit risk of their portfolio possibly holds but does not exclude our explanation either.

Since many foreign owned banks entered the banking sector by purchasing a local bank, one may argue that the acquisition helped them acquire an information base about clients and that the explanation based on information asymmetry would not hold. We consider that while foreign banks in most cases used the purchase of a local bank as a mode of market entry, they adopted new strategies once on the market. Namely, with extensible refinancing, foreign banks aim to gain market share and widen their client base, thus the existing acquired client base represents only a tiny stake of the growing loan portfolio for this kind of banks. Therefore, we can assume that there is probably significant information asymmetry between foreign banks and local firms on the credit market in Serbia. Detragiache et al. (2006) use the same reasoning when they argue that foreign banks naturally have no long tenure relation with firms. In their theoretical model analyzing the impact of foreign bank entry in poor countries, they assume that in these cases foreign banks are less prone to lend to difficult borrowers in terms of information availability, while most potential borrowers in such countries lack usable collateral and reliable accounting information. They add that even when foreign banks enter by purchasing local banks, local market knowledge and relationships with customers may be lost, as distant managers need to impose formal accountability to monitor local loan officers.

Simultaneously, the increasing foreign bank presence measured by the variable Foreign bank share, in estimation 1 and 2 in Table 8 decreases the average quality of banks' portfolios in the whole banking sector. However, this effect is due only to the increasing asset opacity of domestic banks, since the estimated coefficient is higher and more significant on the subset of domestic banks (estimation 3 and 4, Table 8) while it does not exist when the regression is run only on the foreign bank sub-sample (estimations 5 and 6). We are aware that the effect might be due to the fact that the variable Foreign bank share captures some time trend and could thus be correlated with all sorts of macro-economic and macroinstitutional trends. Above all, it could be correlated with asset quality since it may captures the improvements in enforcement of prudential norms. However, the overall share of classified assets in total banking assets does not significantly increase in time during the observed period (see Table 2, column 9) while foreign bank presence does, so that the simple correlation of these two variables (Foreign bank share and Asset quality) is, though positive and significant, quite low (0.16, see Appendix II). In addition, we use the time dummy that 
equals 1 for year 2001 when the most important shift in prudential supervision enforcement took place.

From the finding above it is quite possible that domestic banks pushed by competition pressures tend to lose their higher quality clients and move toward a riskier overall portfolio of borrowers. More transparent borrowers seem to benefit more from increasing competition since they become targets of newly entering foreign banks, the latter phenomena having already been defined in literature as "cream skimming". Another interesting result of the estimation of credit risk is that domestic banks extending a relatively higher percentage of their loans on the short term are likely to have better asset quality (lower credit risk), all other things being equal. Interestingly, short term loans have a positive impact on bank margins (Table 7), as explained in part 5.1. Short term lending seems to be then less competitive than long term lending, as documented also by the greater dispersion of interest rates registered in our on-site survey. The relatively higher share of loans given to enterprises does not imply the lower asset quality. Lending to enterprises, however, provides higher margins (Table 7) and it can then be considered then less competitive and more based on established relations with banks than lending to household is.

Table 8. Estimation results for bank asset quality

\begin{tabular}{|c|c|c|c|c|c|c|}
\hline & \multicolumn{2}{|c|}{ All banks } & \multicolumn{2}{|c|}{ Domestic banks } & \multicolumn{2}{|c|}{ Foreign banks } \\
\hline & $\mathrm{FE}$ & OLS & GLS & OLS & GLS & OLS \\
\hline Variable & $(1)$ & (2) & (3) & (4) & $(5)$ & $(6)$ \\
\hline Equity (over assets) & $\begin{array}{l}0.162 \\
(1.53)\end{array}$ & $\begin{array}{l}0.188 \\
(2.67) * * *\end{array}$ & $\begin{array}{l}0.204 \\
(2.78) * * *\end{array}$ & $\begin{array}{l}0.204 \\
(2.35)^{* *}\end{array}$ & $\begin{array}{l}0.114 \\
(3.18)^{* * *}\end{array}$ & $\begin{array}{l}0.116 \\
(2.40)^{* *}\end{array}$ \\
\hline Administrative costs & $\begin{array}{l}0.425 \\
(0.85)\end{array}$ & $\begin{array}{l}0.226 \\
(0.70)\end{array}$ & $\begin{array}{l}0.196 \\
(0.45)\end{array}$ & $\begin{array}{l}0.196 \\
(0.48)\end{array}$ & $\begin{array}{l}0.279 \\
(1.33)\end{array}$ & $\begin{array}{l}0.413 \\
(2.69) * * *\end{array}$ \\
\hline Market share & $\begin{array}{l}-0.832 \\
(-1.15)\end{array}$ & $\begin{array}{l}0.242 \\
(0.83)\end{array}$ & $\begin{array}{l}0.331 \\
(0.74)\end{array}$ & $\begin{array}{l}0.331 \\
(0.84)\end{array}$ & $\begin{array}{l}0.224 \\
(1.14)\end{array}$ & $\begin{array}{l}0.252 \\
(1.58)\end{array}$ \\
\hline Liquidity & $\begin{array}{l}0.098 \\
(1.01)\end{array}$ & $\begin{array}{l}-0.020 \\
(-0.37)\end{array}$ & $\begin{array}{l}-0.010 \\
(-0.10)\end{array}$ & $\begin{array}{l}-0.010 \\
(-0.12)\end{array}$ & $\begin{array}{l}0.050 \\
(1.21)\end{array}$ & $\begin{array}{l}0.048 \\
(1.23)\end{array}$ \\
\hline Enterprises loans & $\begin{array}{l}0.010 \\
(0.14)\end{array}$ & $\begin{array}{l}0.044 \\
(0.93)\end{array}$ & $\begin{array}{l}0.057 \\
(0.94)\end{array}$ & $\begin{array}{l}0.057 \\
(0.93)\end{array}$ & $\begin{array}{l}0.038 \\
(1.35)\end{array}$ & $\begin{array}{l}0.052 \\
(2.35) * *\end{array}$ \\
\hline Short term loans & $\begin{array}{l}-0.030 \\
(-0.38)\end{array}$ & $\begin{array}{l}-0.156 \\
(-2.44)^{* *}\end{array}$ & $\begin{array}{l}-0.212 \\
(-3.23)^{* * *}\end{array}$ & $\begin{array}{l}-0.212 \\
(-2.47)^{* *}\end{array}$ & $\begin{array}{l}-0.035 \\
(-1.00)\end{array}$ & $\begin{array}{l}-0.054 \\
(-1.42)\end{array}$ \\
\hline Foreign bank share & $\begin{array}{l}0.131 \\
(2.28)^{* *}\end{array}$ & $\begin{array}{l}0.102 \\
(1.73)^{*}\end{array}$ & $\begin{array}{l}0.182 \\
(2.44)^{* * *}\end{array}$ & $\begin{array}{l}0.182 \\
(2.19)^{* *}\end{array}$ & $\begin{array}{l}0.031 \\
(0.92)\end{array}$ & $\begin{array}{l}0.014 \\
(0.46)\end{array}$ \\
\hline Foreign bank & $\begin{array}{l}-0.060 \\
(-1.08)\end{array}$ & $\begin{array}{l}-0.057 \\
(-2.14) * *\end{array}$ & & & $\begin{array}{l}-0.021 \\
(-0.54)\end{array}$ & \\
\hline State-owned bank & $\begin{array}{l}0.161 \\
(1.92)^{*}\end{array}$ & $\begin{array}{l}0.042 \\
(1.58)\end{array}$ & $\begin{array}{l}0.027 \\
(0.91)\end{array}$ & $\begin{array}{l}0.027 \\
(0.94)\end{array}$ & & \\
\hline Merged & & $\begin{array}{l}-0.020 \\
(-0.93)\end{array}$ & $\begin{array}{l}-0.026 \\
(-0.65)\end{array}$ & $\begin{array}{l}-0.026 \\
(-0.95)\end{array}$ & $\begin{array}{l}-0.005 \\
(-0.24)\end{array}$ & $\begin{array}{l}-0.002 \\
(-0.17)\end{array}$ \\
\hline D2001 & $\begin{array}{l}-0.021 \\
(-0.59)\end{array}$ & $\begin{array}{l}-0.011 \\
(-0.39)\end{array}$ & $\begin{array}{l}-0.002 \\
(-0.04)\end{array}$ & $\begin{array}{l}-0.002 \\
(-0.05)\end{array}$ & $\begin{array}{l}0.012 \\
(0.62)\end{array}$ & $\begin{array}{l}0.017 \\
(1.21)\end{array}$ \\
\hline Constant & $\begin{array}{l}-0.033 \\
(-0.35)\end{array}$ & $\begin{array}{l}0.101 \\
(1.58)\end{array}$ & $\begin{array}{l}0.113 \\
(1.37)\end{array}$ & $\begin{array}{l}0.113 \\
(1.44)\end{array}$ & & $\begin{array}{l}-0.015 \\
(-0.4)\end{array}$ \\
\hline $\begin{array}{l}\text { Observations } \\
\text { R-squared }\end{array}$ & $\begin{array}{l}218 \\
0.1527\end{array}$ & $\begin{array}{l}218 \\
0.2613\end{array}$ & $\begin{array}{l}166 \\
0.2337\end{array}$ & $\begin{array}{l}166 \\
0.2337\end{array}$ & $\begin{array}{l}52 \\
0.4695\end{array}$ & $\begin{array}{l}52 \\
0.4809\end{array}$ \\
\hline $\begin{array}{l}\text { F-test, individual effects }=0 \text {, } p \text {-value } \\
\text { Hausman specification test, } p \text {-value }\end{array}$ & $\begin{array}{l}0.0421 \\
0.0190\end{array}$ & & $\begin{array}{l}0.1019 \\
0.4033\end{array}$ & & $\begin{array}{l}0.1664 \\
0.3622\end{array}$ & \\
\hline
\end{tabular}

Notes: t-statistics are in parentheses; *significant at 10\%; ** significant at 5\%;*** significant at 1\%

\section{CONCLUSION}

The opening of the banking market in Serbia is associated with enhanced competition for borrowers, as evidenced both from the on-site banking survey we conducted and from an original dataset covering all banks operating in Serbia in the period from 2001 to 2005. As we 
show in the paper, interest rates however remain extremely dispersed, varying significantly across banks.

Competition on the banking market open to foreign bank entry is likely to produce segmentation on the credit market. The segmentation and concentration of certain bank types on certain segments is determined by bank ownership, the latter being a factor of cost and structure of banking resources as well as of informational friction on the lending market, rather than a determinant of management quality. This is well supported by recent theoretical models for liberalized lending markets with foreign bank entry and competition. Though we only have 5 years of banking data available, we use detailed financial statements for the entire population of Serbian banks. We empirically explain the segmentation of the lending market caused by information asymmetry and differences in funding costs across ownership categories of banks (domestic vs. foreign). Thus we confirm the basic propositions of the theoretical model. We also clarify our intuitive hypothesis concerning the lending market structure in the Serbian transition banking sector formed on the basis of on-site interviews with the management of 19 banks covering $66 \%$ of total banking assets in Serbia by the end of 2005 .

Our main finding is that, although an increasing presence of foreign banks is associated with a deepening of financial intermediation, resulting in an excessive credit offer in the Serbian economy, and although significant credit growth introduces sharper competition in the lending market, the lending market is getting segmented. It seems that more transparent borrowers benefit from competition more, since they belong to the segment where foreign banks are more present and offer better lending terms.

For better understanding of our main findings, we propose in Figure 1, a stylized presentation of the structure of the lending market and the main flows in the banking sector. We believe that the implication of our findings concern financial stability on one side and monetary policy transmission on the other side.

From the aspect of financial stability, there is no decreasing quality of the overall credit market due to increasing competition, although the average quality of domestic banks' assets is decreasing with higher competition from foreign banks; in an environment of credit expansion, vulnerability might increase on the more opaque part of the banking sector and central bank policies should supervise it particularly in order to ensure more stable financial intermediation. On the other hand, due to the existence of two different segments of clients in the lending market and the simultaneous evolution of information friction in time (see Kim et al, 2006), one could imagine that the information advantage could start to disappear for domestic banks. Then, if their cost disadvantage does not improve at the same pace, we could expect, still in light of the used theoretical framework, that foreign-owned banks would capture the whole lending market. As a matter of availability of loans, the latter scenario will not have particularly worrisome consequences. Yet, from a systemic stability point of view, we would suggest some special attention and further investigation.

Understanding the structure of the banking system and the mechanism of interactions in the lending market could shed some light on the transmission mechanism of monetary policy. Instead of observing banks as a passive aggregate, the understanding of banks as independent entities that interact with their environment is a useful hypothesis for further research on the monetary system in transition countries. 
Figure 1. Main characteristics of financial intermediation in Serbia

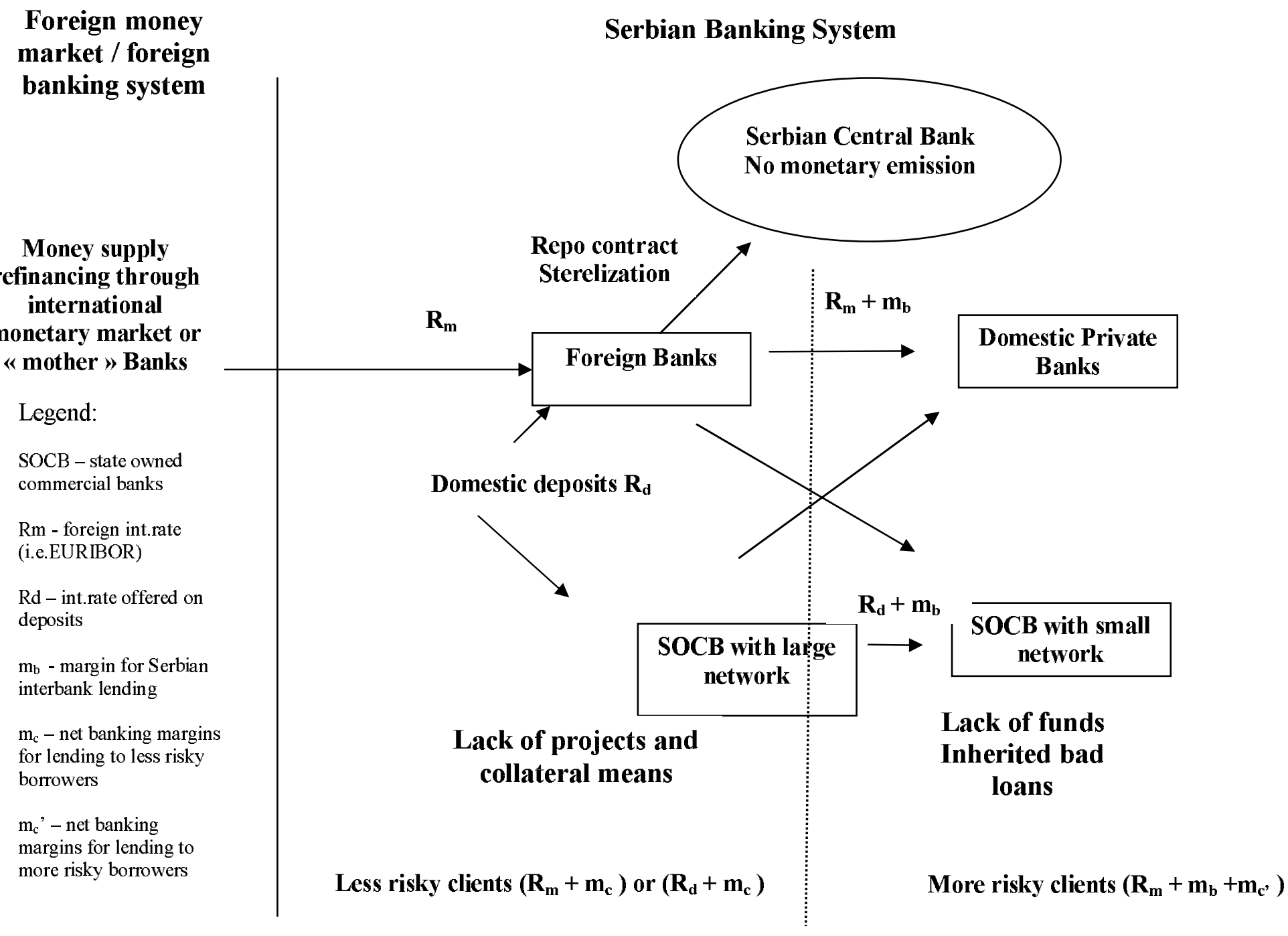




\section{References}

Beck, T. Demirguc-Kunt, A. and Levine, R. (2000) 'A New Database on the Structure and Development of the Financial Sector', The World Economic Review, No.14, pp. 597-605

Berger, A. N. DeYoung, R. (1997) 'Problem loans and cost efficiency in commercial banks', Journal of Banking and Finance 21, 849-870

Bonin, J. Hasan I. and Wachtel, P. (2004) 'Privatization Matters: Bank Efficiency in Transition Countries’, BOFIT Discussion Paper No.8, Bank of Finland

Claessens, S. Demirguc-Kunt, A. and Huizinga, H. (2001) 'How Does Foreign Entry Affect Domestic Banking Markets?', Journal of Banking and Finance, No. 25, pp. 891-911

Claessens, S. and Laeven, L. (2003) 'What Drives Bank Competition? Some International Evidence', World Bank Policy Research Paper No.3113

Claeys, S. and Vennet Vander, R. (2003) 'Determinants of Bank Interest Margins in Central and Eastern Europe. Convergence to the West?', Working Paper No.2003/203, Ghent University

Clarke, R.G.G. Cull, R. and Peria Soledad Martinez, M. Sanchez, S. (2001) Foreign Bank Entry: Experience, Implications for Developing Countries, and Agenda for Further Research, Policy Research Working Paper Series, No.2698, The World bank

Coricelli, F. Mucci, F. and Revoltella, D. (2006) "Household Credit in the New Europe: Lending Boom or Sustainable Growth?", CEPR Discussion Paper No. 5520

Dell'Ariccia and G. Marquez, R. (2004) 'Information and Bank Credit Allocation', Journal of Financial Economics, No. 72, pp. 185-214

Demirguc-Kunt and A. Huizinga, H. (1998) 'Determinants of Commercial Bank Interest Margins and Profitability, Some International Evidence', Policy Research Working Paper No. $1900, \mathrm{IMF}$

Detragiache, E. Tressel, T. (2006) 'Foreign Banks in Poor Countries: Theory and Evidence', IMF Working paper, WP/06/18

Dimitrijevic, J. (2005), 'Interest Rates in Serbia', Quarterly monitor of economic trends and policies in Serbia, $\mathrm{n}^{\circ} 2$, CEVES

Dimitrijevic, J. (2006), 'Non Performing Loans in Serbia - What is the Right Measure?', Quarterly monitor of economic trends and policies in Serbia, ${ }^{\circ} 7, \mathrm{CEVES}$

Duenwald, C. et al. (2005) 'Too Much of a Good Thing? Credit Booms in Transition Economies: The Cases of Bulgaria, Romania, and Ukraine', IMF Working paper No.WP/05/128

EBRD, (2006), Transition report 2006, Finance in transition, November, London 
Ehrman et al. (2003), 'The Effects of Monetary Policy in the Euro Area ', Oxford Review of Economic Policy, No. 19, pp. 58-72

Freixas, X. and Rochet, J.-C. (1999), 'Microeconomics of banking', The MIT Press, Cambridge

Fries, S. Neven, D. and Seabright, P. (2004) 'Competition, Ownership and Bank Performance in Transition', mimeo, EBRD

Ho, T. and Saunders, A. (1981), 'The Determinants of Bank Interest Margins: Theory and Empirical Evidence', Journal of Financial and Quantitative Analysis 4, pp.581-600

IMF (2003), Compilation Guide on Financial Soundness Indicators

Kraft, E. and Jankov, LJ. (2005) 'Does Speed Kill? Lending Booms and their Consequences in Croatia', Journal of Banking and Finance, No.29, pp.105-121

Kim M. et al. (2005), "What Determines Banks' Market Power? Akerlof versus Herfindahl," Working Paper 2005/8, Norges Bank.

Levine, R. (2003) 'Denying Foreign Bank Entry: Implications for Bank Interest Margins', Working paper, No. 222, Central bank of Chile

Mamatzakis, E. Staikouras, C. and Koutsomanoli-Fillipaki, N. (2005) 'Competition and Concentration in the Banking Sector of the South Eastern European Region', Emerging Market Review, No.6, pp. 192-209

National bank of Serbia (2006), 'Statistical Bulletin', various issues

National bank of Serbia (2004, 2005 and 2006), 'Banking system report', various issues

National bank of Serbia, 'Decision on Criteria for the Classification of Balance Sheet and Off-balance Sheet Items According to the Level of Collectability and Special Provisions of Banks and Other Financial Organisations', Official Gazzette of the Republic of Serbia, No. $37 / 2004,86 / 2004$ and 51/2005

National bank of Serbia, Rules on the chart of accounts and content of accounts within the chart for banks and other financial organisations, Official Gazette of the Republic of Serbia, No. $133 / 2003$ and $4 / 2004$

National bank of Serbia, Rules on forms and content of individual items in financial statement forms to be completed by banks and other financial organizations,

Rossi, S. Schwaiger, M. Winkler, G. (2005) 'Managerial Behavior and Cost/Profit Efficiency in the Banking Sectors of Central and Eastern European Countries', Working Paper No.96, Osterreichische Nationalbank

Soledad Martinez Peria, M. Mody, A. (2004) 'How Foreign Participation and Market Concentration Impact Bank Spreads: Evidence from Latin America', Journal of Money, Credit and Banking, Vol.36, No.3, pp.511-537 
Vittas, D. (1991) 'Measuring Commercial Bank Efficiency, Use and misuse of bank operating ratios', IMF WPS 806

Vives, X. (2001) 'Competition in the Changing World of Banking', Oxford Review of Economic Policy, No.17, pp.535-547

Wong, K.P. (1997), 'On the Determinants of Bank Interest Margins under Credit and Interest Rate Risk', Journal of Banking and Finance 21, pp.251-271

Zarruck, E.R. (1989), 'Bank Margin with Uncertain Deposit Level and Risk Aversion', Journal of Banking and Finance 14, pp.803-820 
Appendix I: Criteria for Classification of Bank Claims in Accordance with Degree of Collectability

\begin{tabular}{|c|c|c|c|c|c|}
\hline \multirow{2}{*}{ Criteri $^{1)}$} & \multicolumn{5}{|c|}{ Risk categories } \\
\hline & $\mathbf{A}$ & B & $\mathbf{v}$ & G & $\mathbf{D}$ \\
\hline Overdue payment by & 30 days, exceptionally & 31 to 90 & 91 to 120 & 121 to 180 & over 180 days \\
\hline Assessment of borrower's cash flows & harmoni zed & $\begin{array}{r}\text { appropriate (i.e. } \\
\text { positive cash flow in } \\
\text { the previous business } \\
\text { period) but actual } \\
\text { financial picture point } \\
\text { out to potential future } \\
\text { problems }\end{array}$ & $\begin{array}{l}\text { inappropriate, assets } \\
\text { and liabilities maturity } \\
\text { structure does not } \\
\text { correspond to the } \\
\text { borrower's activity }\end{array}$ & illiquid borrower & borrower is under bankruptcy \\
\hline Borrower's capital structure and level & & & $\begin{array}{r}\text { capital structure and } \\
\text { level do not correspond } \\
\text { to the borrower's } \\
\text { activity }\end{array}$ & unsound borrower & \\
\hline Borrower's disclosed profit & & & & disclosed loss & \\
\hline Legal status of the claim & & & & & legally disputed \\
\hline Borrower's file with bank & & & & & $\begin{array}{r}\text { uncompleted and not up to } \\
\text { date }\end{array}$ \\
\hline $\begin{array}{l}\text { Household loans collateralization and provision with } \\
\text { adequate income }\end{array}$ & & & & & $\begin{array}{l}\text { loan collateralized with } \\
\text { deposit of less than } 20 \% \text { of } \\
\text { outstanding loans, monthly } \\
\text { payment exceeds } 30 \% \text { of } \\
\text { monthly household's income }\end{array}$ \\
\hline
\end{tabular}

Source: NBS, Decision on the Classification of Bank Balance-sheet Assets and Off-balance-sheet Items, 2005.

1) All claims on a single borrower (except when legally disputed) are put into one category - the least favorable one for that borrower. 


\begin{tabular}{|c|c|c|c|c|c|c|c|c|c|}
\hline \multirow[b]{2}{*}{ Variable } & \multirow[b]{2}{*}{ Definition } & \multicolumn{2}{|c|}{$\begin{array}{c}\text { All banks } \\
\text { (218 observations) } \\
\end{array}$} & \multicolumn{2}{|c|}{$\begin{array}{c}\text { State-owned banks ( } 89 \\
\text { observations) }\end{array}$} & \multicolumn{2}{|c|}{$\begin{array}{l}\text { Domestic private banks } \\
\text { (77 observations) }\end{array}$} & \multicolumn{2}{|c|}{$\begin{array}{l}\text { Foreign-owned banks } \\
\text { (52 observations) }\end{array}$} \\
\hline & & Mean & $\begin{array}{r}\text { Standard } \\
\text { deviation }\end{array}$ & Mean & $\begin{array}{l}\text { Standard } \\
\text { deviation }\end{array}$ & Mean & $\begin{array}{l}\text { Standard } \\
\text { deviation }\end{array}$ & Mean & $\begin{array}{l}\text { Standard } \\
\text { deviation }\end{array}$ \\
\hline Net interest margin & $\begin{array}{l}\text { Interst income minus interest expence accrued over earning assets } \\
\text { (total assets net of fixed assets) }\end{array}$ & 0.058 & 0.040 & 0.052 & 0.036 & 0.080 & 0.044 & 0.034 & 0.019 \\
\hline Asset quality & Provisions for non-performing assets over total assets & 0.109 & 0.149 & 0.156 & 0.055 & 0.103 & 0.113 & 0.037 & 0.041 \\
\hline Liquidity & $\begin{array}{l}\text { Excess reserves over assets (cash and sight deposits with central } \\
\text { bank in total assets) }\end{array}$ & 0.224 & 0.148 & 0.190 & 0.156 & 0.257 & 0.146 & 0.235 & 0.128 \\
\hline Equity (over assets) & Bank capital (plus reserves) over assets & 0.274 & 0.233 & 0.201 & 0.255 & 0.409 & 0.186 & 0.196 & 0.155 \\
\hline Funding cost & Interest expences to total loans and deposits received by bank & 0.027 & 0.027 & 0.024 & 0.018 & 0.037 & 0.037 & 0.016 & 0.011 \\
\hline Market share & Share of loans held by bank in loans of whole banking sector & 0.023 & 0.036 & 0.029 & 0.043 & 0.012 & 0.020 & 0.029 & 0.037 \\
\hline Administrative costs & All operating expences over assets & 0.065 & 0.036 & 0.066 & 0.038 & 0.072 & 0.036 & 0.054 & 0.031 \\
\hline Enterprises loans & Loans to enterprises in total loans & 0.313 & 0.910 & 0.316 & 0.214 & 0.330 & 0.147 & 0.283 & 0.167 \\
\hline Short term loans & Share of loans up to 1 year of maturity in total loans & 0.704 & 0.272 & 0.545 & 0.315 & 0.864 & 0.105 & 0.741 & 0.206 \\
\hline Foreign bank share & $\begin{array}{l}\text { Share of loans held by foreign banks in loans of whole banking } \\
\text { sector }\end{array}$ & 0.290 & 0.234 & 0.253 & 0.227 & 0.251 & 0.210 & 0.412 & 0.242 \\
\hline Foreign bank & Dummy equal to 1 for bank owned by a foreign bank & 0.239 & 0.427 & 0.000 & 0.000 & 0.000 & 0.000 & 1.000 & 0.000 \\
\hline State owned bank & Dummy equal to 1 for state owned bank & 0.408 & 0.493 & 1.000 & 0.000 & 0.000 & 0.000 & 0.000 & 0.000 \\
\hline Merged & Dummy equal to 1 for bank closed in a observed period & 0.101 & 0.302 & 0.112 & 0.318 & 0.091 & 0.289 & 0.096 & 0.298 \\
\hline D2001 & Year dummy for 2001, first year of reforms & 0.239 & 0.427 & 0.303 & 0.462 & 0.260 & 0.441 & 0.096 & 0.298 \\
\hline
\end{tabular}


Appendix III: Correlation matrix of variables

\begin{tabular}{|c|c|c|c|c|c|c|c|c|c|c|c|c|c|c|}
\hline & $\begin{array}{c}\begin{array}{c}\text { Net interest } \\
\text { margin }\end{array} \\
\end{array}$ & Asset quality & Liquidity & $\begin{array}{c}\text { Equity (over } \\
\text { assets) }\end{array}$ & Funding cost & $\begin{array}{c}\text { Administrative } \\
\text { costs } \\
\end{array}$ & Market share & $\begin{array}{c}\text { Enter prises } \\
\text { loans }\end{array}$ & $\begin{array}{c}\text { Short term } \\
\text { loans }\end{array}$ & $\begin{array}{c}\begin{array}{c}\text { Foreign bank } \\
\text { share }\end{array} \\
\end{array}$ & Foreign bank & $\begin{array}{c}\text { State-owned } \\
\text { bank }\end{array}$ & Merged & D2001 \\
\hline Net interest margin & 1.0000 & & & & & & & & & & & & & \\
\hline Asset quality & $0.1404 *$ & 1.0000 & & & & & & & & & & & & \\
\hline Liquidity & 0.0538 & -0.1313 & 1.0000 & & & & & & & & & & & \\
\hline Equity (over assets) & $0.5865^{*}$ & $0.1822^{*}$ & 0.1051 & 1.0000 & & & & & & & & & & \\
\hline Funding cost & $0.2064 *$ & $0.2632 *$ & -0.0863 & $0.3243^{*}$ & 1.0000 & & & & & & & & & \\
\hline Administrative costs & $0.4460^{*}$ & $0.1485^{*}$ & $0.2098^{*}$ & $0.2660^{*}$ & $0.1455^{*}$ & 1.0000 & & & & & & & & \\
\hline Market share & $-0.2472^{*}$ & -0.0052 & $-0.1716^{*}$ & $-0.5065^{*}$ & $-0.1386^{*}$ & $-0.2710^{*}$ & 1.0000 & & & & & & & \\
\hline Enter prises loans & $0.2788^{*}$ & $0.2578 *$ & -0.1008 & $0.3336^{*}$ & $0.2786^{*}$ & 0.0581 & -0.0206 & 1.0000 & & & & & & \\
\hline Short term loans & $0.4559^{*}$ & $-0.2297^{*}$ & $0.4475^{*}$ & $0.4656^{*}$ & 0.0841 & $0.2796^{*}$ & $-0.2655^{*}$ & -0.0974 & 1.0000 & & & & & \\
\hline Foreign bank share & 0.1222 & $0.1601 *$ & $0.1347^{*}$ & 0.0706 & -0.0386 & $0.4063 *$ & 0.0664 & $0.1490 *$ & 0.0522 & 1.0000 & & & & \\
\hline Foreign bank & $-0.3347^{*}$ & $-0.2696 *$ & 0.0511 & $-0.1828 *$ & $-0.2239 *$ & $-0.1768 *$ & 0.0881 & $-0.1762 *$ & 0.0789 & $0.2909^{*}$ & 1.0000 & & & \\
\hline State-owned bank & -0.1277 & $0.2601 *$ & $-0.1835^{*}$ & $-0.2531 *$ & -0.0864 & 0.0099 & $0.1455^{*}$ & -0.0651 & $-0.4868 *$ & $-0.1343 *$ & $-0.4681 *$ & 1.0000 & & \\
\hline Merged & -0.0228 & -0.1057 & 0.0519 & -0.0797 & $0.1493 *$ & 0.0021 & $-0.1527^{*}$ & -0.1166 & 0.0034 & $-0.1569 *$ & -0.0097 & 0.0303 & 1.0000 & \\
\hline D2001 & $-0.2039 *$ & $-0.1446 *$ & $-0.1380^{*}$ & $-0.2059 *$ & 0.0186 & $-0.4931 *$ & -0.0635 & $-0.2913^{*}$ & $-0.1946^{*}$ & $-0.6446^{*}$ & $-0.1887^{*}$ & 0.1245 & $0.1333^{*}$ & 1.0000 \\
\hline
\end{tabular}

Source: Author's calculations

Appendix IV : Asset and liabilities structure

\begin{tabular}{|c|c|c|c|c|c|c|c|c|c|c|c|c|c|c|c|c|c|c|}
\hline & \multicolumn{3}{|c|}{2000} & \multicolumn{3}{|c|}{2001} & \multicolumn{3}{|c|}{2002} & \multicolumn{3}{|c|}{2003} & \multicolumn{3}{|c|}{2004} & \multicolumn{3}{|c|}{2005} \\
\hline & $\begin{array}{c}\begin{array}{c}\text { State } \\
\text { owned } \\
\text { banks }\end{array} \\
\end{array}$ & $\begin{array}{c}\text { Domestic } \\
\text { private } \\
\text { banks }\end{array}$ & $\begin{array}{c}\text { Foreign- } \\
\text { owned } \\
\text { banks }\end{array}$ & $\begin{array}{c}\text { State } \\
\text { owned } \\
\text { banks } \\
\end{array}$ & $\begin{array}{c}\text { Domestic } \\
\text { private } \\
\text { banks }\end{array}$ & $\begin{array}{c}\text { Foreign- } \\
\text { owned } \\
\text { banks }\end{array}$ & $\begin{array}{c}\begin{array}{c}\text { State } \\
\text { owned } \\
\text { banks }\end{array} \\
\end{array}$ & $\begin{array}{c}\text { Domestic } \\
\text { private } \\
\text { banks } \\
\end{array}$ & $\begin{array}{c}\text { Foreign- } \\
\text { owned } \\
\text { banks }\end{array}$ & $\begin{array}{c}\begin{array}{c}\text { State } \\
\text { owned } \\
\text { banks }\end{array} \\
\end{array}$ & $\begin{array}{c}\text { Domestic } \\
\text { private } \\
\text { banks } \\
\end{array}$ & $\begin{array}{c}\text { Foreign- } \\
\text { owned } \\
\text { banks }\end{array}$ & $\begin{array}{c}\text { State } \\
\text { owned } \\
\text { banks }\end{array}$ & $\begin{array}{c}\text { Domestic } \\
\text { private } \\
\text { banks } \\
\end{array}$ & $\begin{array}{c}\text { Foreign- } \\
\text { owned } \\
\text { banks }\end{array}$ & $\begin{array}{c}\text { State } \\
\text { owned } \\
\text { banks }\end{array}$ & $\begin{array}{c}\text { Domestic } \\
\text { private } \\
\text { banks }\end{array}$ & $\begin{array}{r}\text { Foreign- } \\
\text { owned } \\
\text { banks } \\
\end{array}$ \\
\hline \multirow{2}{*}{\multicolumn{19}{|c|}{ (in \% of total assets) }} \\
\hline & & & & & & & & & & & & & & & & & & Assets \\
\hline Fixed assets & 2.58 & 7.30 & n.a. & 2.77 & 6.16 & 2.11 & 6.71 & 7.91 & 3.29 & 8.70 & 7.76 & 3.39 & 9.23 & 8.91 & 2.93 & 8.48 & 10.47 & 4.38 \\
\hline Loans to other financial instititions & 15.78 & 8.61 & n.a. & 27.34 & 9.05 & 14.06 & 8.24 & 9.87 & 26.03 & 11.92 & 11.49 & 19.01 & 13.40 & 10.19 & 14.55 & 3.78 & 5.92 & 4.29 \\
\hline Loans to citizens & 0.34 & 1.72 & n.a. & 0.45 & 1.53 & 1.72 & 5.04 & 4.50 & 5.01 & 7.72 & 5.99 & 10.73 & 9.50 & 7.62 & 19.22 & 12.02 & 7.26 & 18.40 \\
\hline Loans to enterprises & 29.30 & 23.70 & n.a. & 25.17 & 28.80 & 4.64 & 43.77 & 38.42 & 14.68 & 35.60 & 35.78 & 33.12 & 33.77 & 33.63 & 40.15 & 30.15 & 38.06 & 35.62 \\
\hline Loans to government & 34.50 & 0.50 & n.a. & 22.29 & 1.32 & 0.00 & 2.73 & 1.66 & 0.00 & 3.04 & 0.92 & 0.00 & 3.21 & 0.73 & 0.00 & 0.99 & 2.27 & 0.28 \\
\hline Securities held & 0.86 & 2.82 & n.a. & 0.65 & 3.92 & 0.19 & 1.62 & 2.24 & 2.50 & 1.95 & 1.71 & 4.61 & 1.79 & 2.21 & 2.57 & 4.09 & 3.52 & 1.65 \\
\hline Shares in equity & 0.94 & 3.09 & n.a. & 1.09 & 2.10 & 0.01 & 0.77 & 1.17 & 0.00 & 1.43 & 1.86 & 1.13 & 1.71 & 1.35 & 2.59 & 0.74 & 2.00 & 1.46 \\
\hline Other assets & 10.48 & 17.44 & n.a. & 15.17 & 20.94 & 41.24 & 15.13 & 12.23 & 23.31 & 10.81 & 8.78 & 11.86 & 10.71 & 10.72 & 5.60 & 10.30 & 7.52 & 4.18 \\
\hline $\begin{array}{l}\text { Cash and cash equivalents } \\
\text { (in } \% \text { of total liabilities) }\end{array}$ & 5.21 & 34.82 & n.a. & 5.07 & 26.18 & 36.03 & 15.99 & 22.00 & 25.17 & 18.82 & 25.70 & 16.15 & 16.68 & 24.65 & 12.39 & 29.46 & 22.97 & 29.73 \\
\hline \multicolumn{19}{|l|}{ Liabilities } \\
\hline Equity & -0.07 & 41.66 & n.a. & -36.30 & 39.83 & 15.21 & 14.78 & 33.45 & 12.88 & 23.10 & 31.53 & 14.76 & 22.75 & 29.28 & 10.21 & 18.47 & 43.50 & 12.29 \\
\hline Deposits and loans from other local banks & 29.39 & 3.90 & n.a. & 25.18 & 3.83 & 3.85 & 10.23 & 6.34 & 8.74 & 11.45 & 8.38 & 5.98 & 8.04 & 4.88 & 8.59 & 5.11 & 5.30 & 3.23 \\
\hline Deposits and loans from foreign entities & 16.35 & 2.81 & n.a. & 32.05 & 1.31 & 4.87 & 5.39 & 1.95 & 5.74 & 4.47 & 2.18 & 14.08 & 4.79 & 3.17 & 31.02 & 3.70 & 2.93 & 32.81 \\
\hline Citizens FX deposits & 32.70 & 2.96 & n.a. & 23.57 & 4.97 & 40.21 & 10.59 & 9.69 & 38.31 & 17.06 & 13.27 & 33.07 & 24.14 & 17.42 & 23.20 & 31.66 & 10.97 & 23.96 \\
\hline Citizens dinar deposits & 0.35 & 0.70 & n.a. & 0.50 & 0.81 & 0.11 & 5.31 & 2.21 & 0.56 & 6.87 & 2.38 & 1.10 & 5.98 & 2.43 & 1.01 & 5.88 & 1.70 & 1.97 \\
\hline Deposits and loans from enterprises & 4.64 & 27.38 & n.a. & 4.65 & 28.04 & 30.46 & 18.91 & 31.30 & 26.90 & 21.70 & 35.85 & 27.81 & 20.77 & 31.91 & 21.86 & 21.99 & 24.98 & 18.30 \\
\hline Government deposits and loans & 0.55 & 1.02 & n.a. & 0.87 & 4.16 & 22.00 & 7.98 & 4.58 & 1.95 & 4.98 & 0.94 & 0.28 & 3.95 & 4.34 & 0.65 & 4.39 & 3.18 & 1.81 \\
\hline Other liabilities & 16.08 & 19.56 & n.a. & 49.48 & 17.05 & 5.08 & 26.80 & 10.47 & 4.92 & 10.38 & 5.48 & 2.92 & 9.58 & 6.58 & 3.46 & 8.80 & 7.44 & 5.64 \\
\hline
\end{tabular}

